УДК 821.111(6-13)'06-312.1.09(045)

Алла Полторацька

\title{
ДИНАМІКА СПРИЙНЯТТЯ ТВАРИН ДЕВІДОМ ЛУР' У РОМАНІ ДЖОНА МАКСВЕЛЛА КУТЗЕЕ «БЕЗЧЕСТЯ»
}

\section{Вступ}

Наприкінці XX століття спостерігаємо парадигмальну зміну в розумінні людиною тварини. Людина все більше вбачає в не-людині істоту, якій можна довіритися. Вона наближає до себе тварину, знаходить у ній ласку та підтримку. Тварина постає джерелом любові, опори та всього того, чого бракує людині в житті. Нелюдина трактується як рівна людині, навіть ближча людині, аніж людина людині, адже тварина часто допомагає подолати кризу, що переживає людина. За таких умов формується нова тенденція у баченні людиною тваринного світу.

Американська дослідниця Донна Геревей зауважувала, що всі ми перебуваємо в центрі заплутаної павутини, яку утворюють різні істоти, що взаємодіють, серед них тварини, хвора дитина, село, свині, лабораторії, передмістя, виробництва і економіки, екології, які формують нескінчені зв'язки між природою та культурами (Haraway, 2008: 72). У цій заплутаній павутині людина вибудовує новий ракурс відносин із твариною. Філософи відчули цю трансформацію, тому почали показувати інше ставлення до не-людини: тварина постала і як важлива цінність, і як товариш. Художня література теж реагує на такий поворот у тлумаченні відносин між людиною і твариною. Зокрема, це проявляється на рівні образів, наративних стратегій та художніх засобів. Низка письменників (Дж. Боуен, Б. Вербер, М. Єргович, М. Кундера, 3. Нунез, О. Токарчук, Дж. Фоєр) переосмислюють бінарне протистояння між homo sapiens і тваринами.

У центрі нашого дослідження роман «Безчестя» (1999) Джона Максвелла Кутзее. Критичні дослідження твору головним чином зосереджені на вивченні постколоніального виміру, питаннях раси (C) Алла Полторащька, 2020

http://dx.doi.org/10.34142/2312-1076.2020.2.96.07 
та гендерної нерівності. У низці наукових праць проаналізовано різні аспекти цього роману: наприклад, Джейн Пойнер (Poyner, 2000) у статті «Правда та примирення у «Безчесті» Дж.М. Кутзее» дослідила етичний пласт; Аріелла Азулей у роботі «An Alien Woman/A Permitted Woman: On J.M. Coetzee's Disgrace» (Azoulay, 2002) розглянула репрезентації жіночих образів, Сюзан Сміт-Маре у розвідці «Subverting the pastoral: the transcendence of space and place in J.M. Coetzee's “Disgrace”» (Smit-Marais, 2006) проаналізувала трансценденталізм місця і простору у творі. Польські дослідники теж цікавляться романом Дж.М. Кутзее. Зокрема, Юлія Валласек (Vallasek, 2011) осмислила проблему жорстокості у «Безчесті». Аналіз творчості Дж.М. Кутзее здійснено і в Україні. Так, М. Пшенична виокремила основні тенденції та підходи до вивчення поетики романів Дж.М. Кутзее (Пшенична, 2017: 27).

Об 'єкт цієї статті - роман Джона Максвелла Кутзее «Безчестя».

Предмет дослідження - особливості рецепції Девідом тварин у романі.

Мета статті - прослідкувати метаморфозу Девіда Лур'є та його ставлення до тварин у романі Джона Максвелла Кутзее «Безчестя».

\section{Методологія та методи дослідження}

Теоретичну базу дослідження становлять праці Дж. Агамбена, Ж. Симондона, Ж. Дерріди, Т. Інгольда, Л. Калоф, А. Ліппіт, Е. Фадж, Р. Брайдотті та ін. Вони забезпечили комплексний підхід до розуміння проблеми та системність дослідження.

Із огляду на мету й предмет дослідження в роботі використано порівняльний аналіз критичних праць для окреслення основних тенденцій специфіки творчості Дж.М. Кутзее в українському та зарубіжному літературознавстві; герменевтичний аналіз художнього тексту, що необхідний для виявлення специфіки ставлення Девіда Лур'є до тварин. Крім того, застосовано елементи описового, порівняльного й рецептивно-інтерпретаційного методів.

\section{Результати та дискусії}

Поряд із вже вказаними проблемами предметом уваги сучасних науковців (К. Віегант, А. Хеєрдена, М. Дековен, Т. Херрон та ін.) 
$€$ питання взаємодії людини 3 твариною у романі Дж.М. Кутзее «Безчестя». Деякі з них (К. Віегант) порівнюють погляди головного персонажа $з$ поглядами Діогена Синопського (Wiegandt, 2013). Інші пов'язують роман із висвітленням ролі собак у Південній Африці, які захищали «білих» людей (Pölling-Vocke, 2004) і сприймалися як уособлення їхньої влади.

Адріан ван Хеєрден упраці «Disgrace, Desire, and the Dark Side of the New South Africa» проаналізував роман «Безчестя» в трьох ракурсах: розглянув концепти безчестя, сорому, провини, втрати людяності; осмислив природу та об'єкт бажання; розглянув метаморфозу пса-людини, яка сигналізує про реконструкцію відмінностей між тваринами і людьми. Хеєрден виокремив нову площину в розумінні взаємодії людини з твариною, помітивши заклик автора до перегляду розуміння світу (Heerden, 2010: 43-64). Вчений відзначив, що варто ставитися $з$ добротою і повагою як до людей, так і до тварин.

Маріанн Дековен у дослідженні «Going to the Dogs in Disgrace» детально проаналізувала проблемно-тематичний та образний рівні тексту. Дослідниця не оминає питання раси, видової дискримінації та гендерної нерівності. Разом з тим вона вказує і на зміни у внутрішньому світі головного персонажа, переоцінку його світогляду щодо тварин» (Dekoven, 2009: 847-875).

Джоллі Росемарі досліджувала, наскільки пов'язані між собою гуманність, гуманітаризм та патріархальна культура, які формують одну культуру. Крім того, вона розглянула ряд проблем, серед яких розуміння самої людини» якою вона є без урахування традиційних видових меж (Rosemary, 2009). Росемарі вказала, що людське бачення тварин сфокусоване на мові, через яку вимірюється етична цінність людства (Rosemary, 2009: 148 -171).

Том Херрон прослідкував, як життя не-людини стирається людиною, яка задовольняє свої інтереси та потреби, та спостерігав за змінами в образі Девіда (Herron, 2005: 467-490). При цьому, кожен iз дослідників вбачає безчестя як у стосунках між людьми, так і у відношенні людей до тварин. Отже, вчені зацікавлені у вирішенні 
питання взаємодії людини і тварини в романі «Безчестя», та в аналізі образів твору, а особливо - головного персонажу, Девіда Лур'є.

Девід Лур'є - професор Технічного університету Кейпа. Йому п'ятдесят два роки. На перший погляд, Девід успішний чоловік, його життя цілком забезпечене. Однак із розвитком сюжету розкривається його не така вже й щаслива доля. На роботі він не вражає студентів, адже «він ніколи не був великим педагогом» (Кутзее, 2017: 9) і «не поважає матеріал, який викладає» (Кутзее, 2017: 9). Девід зізнається, що вчителем став «випадково», «щоб заробити на життя», а до цього він «був одним із тих, кого називають вченими. Я писав книжки про мертвих людей. Це було мені до душі» (Кутзее, 2017: 164).

В особистому житті Девіда теж не все гаразд. Жіноча родина, у якій він виріс, «зробила з нього жіночого шанувальника та заразом розпусника» (Кутзее, 2017: 11). Він двічі розлучений, задовольняється тимчасовими стосунками. На початку твору Девід перебуває у стосунках із Серайєю, повією, якій платить за послуги і поряд із якою насолоджується життям. Наступним його захопленням стає студентка 3 курсу, Мелані Ісаакс, яка подає скаргу на професора за сексуальні домагання. Дисциплінарна комісія пропонує йому публічно визнати моральну та професійні провини та вибачитися. Проте Девід воліє піти з роботи і втратити все. Гучний скандал змушує Лур'є до зміни місця проживання. Він їде до доньки Люсі, яка живе в селі, в якому утримує ферму та притулок для тварин. По приїзді родина Лур'є має щиру розмову про недавні події в університеті. Ситуацію з Мелані Девід пояснює Люсі на прикладі життя тварин. У розмові $з$ донькою професор замислюється над правильністю дій людини: «Можна покарати собаку за якусь провину на кшталт погризеного капця. I собака погодиться зі справедливістю цього покарання: ти гризеш тебе б'ють. Але бажання - зовсім інша справа. Жодна тварина не погодиться зі справедливістю покарання за те, що керувалася інстинктами» (Кутзее, 2017: 93). Лур'є розглядає знищення капця як знищення майна, а вираження сексуальності $є$ природним i тому не має каратися. На думку Харрінтона, в цьому епізоді Кутзее звертає увагу на те, як зазвичай вчиняє людина: присвоює тваринам 
людські риси і відмовляє їм у прояві волі, що «засвідчило питання бінарності у розумінні видів» (Harrington, 2013:58). Таким чином, професор виправдовує власну поведінку щодо Мелані та заперечує відповідальність за свої дії.

Під час перебування в селі, Девід Лур'є перестає бути байдужим до тварин і починає співчувати їм. Показовий епізод із вівцями, чию долю визначає темношкірий Петрус, який не лише управляє фермою Люсі, але і володіє частиною їі землі. 3 нагоди отримання своєї частки Петрус влаштовує свято: купує двох овець, яких прив'язує «на лисому шматку землі» (Кутзее, 2017: 125), бо ж за декілька днів їх чекає смерть. Тварини постають безправними та пригнобленими. Їхній господар Петрус не дає їм їжі і тримає на пекучому сонці. У цей момент відбувається зміна у поглядах Девіда, який замислюється над поведінкою Петруса. Свої думки професор озвучує доньці: «Привести додому двійко приречених створінь, щоб познайомити з людьми, котрі їх з'їдять» (Кутзее, 2017: 125). Девід вбачає у таких діях чоловіка бездушність і немилосердність, тому намагається потурбуватися про них перед їхнім забиттям. Утім Люсі, яка все життя прагне допомагати тваринам, дії Петруса трактує з традиційного погляду: «Це - село. Це - Африка» (Кутзее, 2017: 125). Таке ставлення - норма і всіх задовольняє. Більшість людей вбачає в тваринах лише задоволення потреб людини: «М'ясо з'їсти, кістки розмолоти і згодувати птиці. Ніщо не врятується, окрім, можливо, жовчного міхура, який ніхто не захоче їсти. Декарту слід було замислитися над цим. Душа, підвішена в темряві гіркого жовчного міхура, - непогана схованка» (Кутзее, 2017: 125). Люсі зауважує, що забій тварин має назву «соuntry ways» (Кутзее, 2017: 129-131), хоча Девід трактує це по-іншому: «Він має інші назви: байдужість і безсердечність. Якщо село може засуджувати місто, то й місто теж може засуджувати село» (Кутзее, 2017: 126) за таке поводження 3 тваринами. Мерлін Столкер вважає, що у романі Лур'є представляє декартову філософію, яка знаменує поділ між раціональною людиною та нераціональною твариною. Хоча професор і погоджується з думкою Люсі, що вищого життя не існує 
і що це єдине життя. (Stolker, 2012: 56), проте такий підхід провокує Девіда до роздумів. Професор має намір викупити вівці, хоча й не знає, що з ними робитиме далі. Лур'є відчуває з тваринами «якийсь зв'язок, сам не розуміє чому... Цей зв'язок поєднав його не з цими двома конкретними вівцями, котрих він навіть не впізнав би серед отари в полі. Хай там як, раптово і безпричинно їхня доля стає для нього важливою» (Кутзее, 2017: 127). Думки змінюються, але звичні дії залишаються. На святі в Петруса він все ж куштує м'ясо цих тварин. Таким чином, зміни у сприйнятті тварин головним персонажем відбуваються повільно.

Девід Лур'є стає волонтером у притулку для тварин, яким керує Бев Шоу. Вона не ветлікарка, а жінка, яка «абсурдно намагається полегшити тягар стражденних африканських тварин» (Кутзее, 2017: 87). Бев розуміє тварин не так, як Девід, для якого тварини інакші, ніж люди, «геть інші» створіння, «не обов'язково вищі, просто інакші» (Кутзее, 2017: 79). Шоу вбачає у тваринах чуттєвість та розум. Бев вважає, що поїдання тварин некорисне, і їі турбує те, як людина виправдається перед ними в майбутньому. Вона ставиться до тварин iз повагою, бо переконана, що останні заслуговують не лише на гуманне поводження $з$ ними, але і на безболісну смерті. Вона теж інша: не соромиться спілкуватися $з$ тваринами і розмовляє 3 ними, як iз рівними: «“Що ти кажеш, друже? - він чує, як шепоче Бев. Що ти кажеш? Досить уже?” Цап стоїть, як стовп, наче його загіпнотизували» (Кутзее, 2017: 88). Девід починає прислухатися до іiі слів, прагне поглянути на традиційний погляд людино-тваринної взаємодії без звичних меж. За таких умов головна відмінність між людиною і нелюдиною - мова - зникає. Таким чином, стає зрозумілим, що Девід зрікається матеріального на користь трансцендентного(Giles, 2012:2), така трансформація впливає на еволюцію персонажа.

На початковому етапі роботи в притулку, ставлення Девіда до тварин полягає у «любові» лише до деяких тварин, бо він їх їсть. Таким поглядом професор підтримує традиційну релігійнокультурну позицію в ставленні до не-людей, відповідно до якого нелюдина постає предметом, бо підлегла людині, що обгрунтовується 
як із релігійного боку: «Отці церкви вважають, що тварини не мають справжньої душі. Їхні душі пов'язані з тілами і помирають разом із ними» (Кутзее, 2017: 81), так і з суспільного: «Ліга добробуту тварин колись була активною благодійною організацією Ірехемстауна, а тепер припинила свою діяльність. Проте кілька добровольців на чолі з Бев Шоу й досі підтримують у старому приміщенні ветеринарну клініку. <..> Фінансування більше немає. Тварини зникли зі списку державних пріоритетів» (Кутзее, 2017: 76). Однак Бев Шоу присвячує себе покинутим тваринам і гуманному поводженню 3 ними, що змушує Девіда замислитися над звичним розумінням тварин, відповідно до якого не-людина задовольняє потреби людей, а знищення безпритульних тварин вітається законом (Harrington, 2013:14-15).

Світогляд батька Люсі щодо розуміння тварин змінюється, бо Бев його навчає. Від початку вона пояснює Девіду, що тварина відчуває людину, тож Девід мусить «думати про щось заспокійливе, про щось хороше. Вони можуть дізнатися, про що ви думаєте» (Кутзее, 2017: 84). Шоу наділяє тварину почуттями, чим порушує традиційне розуміння Девідом людського і не-людського, ієрархічного бачення світу. Спочатку думки Бев викликають сумніви у професора: «“Вони можуть відчути, про що ви думаєте”: що за дурниці!» (Кутзее, 2017: 86). Узвичаєні погляди Лур'є зазнають змін завдяки поясненням Бев. Ця жінка втілює інший ракурс у розумінні як тварин загалом, так і покинутих тварин зокрема. Її ставлення відмінне від бачення професора, завдяки чому Девід помічає в не-людях щось інше, те, що до цього моменту йому було невідомим. Пройшов час, i професор починає замислюється чи варто йому «стати таким, як Бев Шоу» (Кутзее, 2017: 128), якій відома якась хитрість, якої він не знає. Поміч Лур'є в притулку - індикатор спотворених стосунків людства 3 тваринами-компаньйонами, яких людина все частіше ототожнює 3 речами, що легко замінити чи позбутися (Harrington, 2013:14-15).

Поступово Девід бачить не-людей по-новому. Трансформація у розумінні світу тварин професором відбувається пролонговано, завдяки особистому контакту 3 тваринами. Його сильно вражає 
пильний погляд тварини, якій лікують абсцес, коли «...на якусь мить переповнений гнівом і страхом погляд пса зустрічається з його власним» (Кутзее, 2017: 83). Під цим поглядом професор демонструє слабкість, хоча внутрішньо він залишається байдужим до тварини.

Життєві обставини (згвалтування трьома чоловіками Люсі та їхня спроба спалити Девіда живцем) змінюють звичний хід думок професора. Він нині дивитися на тварин «іншими очима» і сам стає іншим. Марлін Стокер вбачає в образі головного персонажа певний «катарсичний досвід», що призводить до зміни в розумінні ним життя (Stolker, 2015). Девід помічає, що тварини здатні відчувати наближення своєї смерті: «Вони майже не б'ються. Дрібні та слабкі тримаються позаду, примирились із долею і чекають своєї черги. $<\ldots>$ Жодних класів. Жоден не вважає себе високопоставленим і могутнім» (Кутзее, 2017: 88-90). Собаки «відчувають, що відбувається всередині. Вони притискають вуха та опускають хвости, ніби вони теж відчувають ганьбу перед смертю; вони так стискають ноги, що ïх доводиться тягнути» (Кутзее, 2017: 145). Найгірші для Девіда моменти, коли вони «нюхають його і лижуть йому руки. Навіщо прикидатися друзякою. Коли ти насправді вбивця?» (Кутзее, 2017: 145). 3 часом він робить так, як Бев: «дозволяє облизувати себе, якщо їм хочеться, так само, як Бев Шоу гладить їх і цілує, якщо вони дозволяють йому» (Кутзее, 2017: 145). Девід починає ставитися до них 3 повагою. Він не залишає мертві тіла тварин у розпорядженні персоналу сміттєспалювального заводу, бо не бажає полишати їх серед «іншого непотребу. <...> Він не готовий завдати їм такої ганьби» (Кутзее, 2017: 146).

Таким чином, образ Девіда Лур'є зазнає динаміки: на початку роману він байдуже ставиться до світу, що його оточує, а наприкінці твору з професором відбуваються певні метаморфози. Це передано через зміну прізвища Лур'є на Лоурі, змінах у ставленні до тварин та перетворенні Девіда в «dog-man: a dog undertaker; a dog psychopomp; a harijan» (Кутзеe, 2017: 151). Він вирішує «присвяти себе служінню мертвим собакам» (Кутзее, 2017: 151), що засвідчує про відхід героя від традиційних норм і стереотипів. Його життя 
нагадує життя Грегора Замзи Ф. Кафки: «Кімната темна, задушлива, захаращена меблями, матрац грудкуватий. Але він звикне до цього, як звикав до всього іншого» (Кутзее, 2017: 211). До кінця твору його потреби скорочуються до сну, їжі й роботи: «Після сніданку він вирушає до клініки та проводить там цілі дні, кожен день, включно 3 неділями» (Кутзее, 2017: 211). Такий стиль життя головного персонажа сигналізує про його протест проти байдужого ставлення людей до світу тварин. Він відмовляється від звичайного режиму, своїх поглядів, вподобань та прагнень. Девід присвячує себе евтаназії та кремації собак. Це він робить «для себе» (Кутзее, 2017: 150-151), бо працівники сміттєспалювального заводу б'ють мертвих тварин «зворотним боком своїх лопат, аби переламати заціпенілі лапи. Саме тоді він втрутився і взявся за роботу самостійно $<\ldots . .>$ заради себе. Заради своїх уявлень про світ, у якому чоловіки не завдають шкоди мертвим тваринам. <..> Можливо, він не їх рятівник <...>, але він готовий піклуватися про них, коли вони самі не зможуть, абсолютно не зможуть піклуватися про себе, навіть коли Бев Шоу залишить їх» (Кутзее, 2017: 147). Девід не може вчинити по-іншому, бо це суперечитиме його новому баченню світу. Дж. Кутзее показує метаморфозу персонажа: «Такий егоїст, як він, присвячує себе служінню мертвим собакам» (Кутзее, 2017: 147). Лур'є обмірковує й інші напрями зміни світу. «Мусять існувати інші, результативніші шляхи, аби віддати себе світові чи своїм уявленням про світ. Можна, приміром, працювати довше в лікарні, <...> існують інші способи служінню людству. <...> Лише він охороняє честь мертвих тварин» (Кутзее, 2017: 147). Догляд за мертвими тілами тварин $\epsilon$ безрезультатним зобов'язанням, яке не заспокоює експлуатованих і вбитих тварин, проте дає полегшення тим, хто за це відповідає (Harrington, 2013:55). Девід хоч і допомагає в притулку, проте він у цей самий час продовжує брати участь у вбивстві собак та спаленні їх тіл.

Переоцінка світу спричинює внутрішній конфлікт у душі професора. Цей неспокій зникає після смерті небайдужої йому собаки. «Серед псів у загонах є один, до котрого він має особливе 
ставлення. Це молодий песик із паралізованою задньою лівою лапкою, яку він тягне за собою <...> Ніхто з відвідувачів не виявляє бажання забрати його <...> Тож пес має скоритися голці» (Кутзее, 2017: 214). Професор не вважає тварину своєю власністю, «пес у жодному разі не “його”. Лур'є не проявляє бажання називати його» (Кутзее, 2017: 219-221), ставати його господарем, утім пес «помре заради нього» (Кутзее, 2017: 221). Девід не рятує собаку, не відтерміновує години смерті, не голубить близьку йому тварину, що «крутить понівеченим задом, нюхає його обличчя, лиже щоки, його губи, вуха» (Кутзее, 2017: 219), а лише ставить «на ньому хрест» (Кутзее, 2017: 225), бо «однаково настане час <...>, коли він принесе пса в операційну до Бев Шоу (мабуть, тоді він занесе його на руках, зробить це для нього)» (Кутзее, 2017: 218). В останні миті життя пса Лур'є дає можливість йому проявити почуття. Професор «не робить нічого, аби зупинити його емоції» (Кутзее, 2017: 225). Під час евтаназії собаки Девід «розсовує шерсть так, аби голці легше було знайти жилу» (Кутзее, 2017: 218), але і проявляє турботу: «шепоче йому щось, підтримує» (Кутзее, 2017: 218). Він стає поряд 3 ним, «об'єднує» свою свідомість і свідомість пса. Він нарешті розуміє, чого бажає тварина перед смертю. Лур'є «поділяє» його біль. У цей момент головний персонаж усвідомлює прірву між власним світорозумінням і загальноприйнятним. Смерть тварини, з одного боку, стає черговою жертвою заради порятунку світу (зменшення кількості безпритульних тварин), а з іншого - ще однією безглуздою загибеллю. Поряд із цим можна виокремити третій ракурс у розумінні смерті цієї тварини - показ автором смерті собаки не лише «як частини меблів, частини сигналізації» (Кутзее, 2017: 82), але і як тварини-компаньйона, близького друга (Harrington, 2013:46). Тож у фіналі роману Девід Лур'є не лише змінює традиційний погляд на тваринно-людські стосунки, але і вказує шлях до розуміння тварини. Дж.М. Кутзее говорив про продовження та розширення експлуатації тварин, утім людство може навчитися розпізнавати цю експлуатацію (Harrington, 2013:70) та уникати їі. 


\section{Висновки}

Традиційно людство трактувало тварину як істоту, яка підпорядковувалася людині і стояла на одному 3 нижніх щаблів ієрархічної драбини. Ч. Дарвін виступив проти цієї опозиції та змінив узвичаєне сприйняття людини. Його праці поставили під сумнів трактування тварини як «автомата» без мови, без почуттів та без розуму. Сучасні письменники прагнуть переосмислити протистояння людини й тварини. Джон Максвелл Кутзее в романі «Безчестя» теж не оминає цю проблему. Автор констатує кризу антропоцентричного світогляду. У романі «Безчестя» він прагне показати трансформацію світогляду головного персонажа під впливом життя на фермі. На початку твору Девід - впевнений чоловік і не цікавиться тваринами, проте наприкінці твору він зовсім інший. Переворот у розумінні світу професора пов'язаний із кількома визначальними моментами його життя: завершенням відносин із коханкою Серайєю, домаганнями до студентки, спілкуванням із Люсі, роботою в притулку та смертю триногого друга (якого Бев називає «Триніжок»). Таким чином, взаємодія між головним персонажем та тваринами впливає на світосприйняття Девіда та розуміння ним світу природи та місця людини на Землі. Кутзее пропонує власну теорію про відносини між людиною й твариною, яка спонукає читача до переосмислення свого місця у світі.

Нова перспектива відкриває сучасний етап взаємодії між людиною та твариною, яка потребує детального вивчення, що становить перспективу наших подальших досліджень.

\section{Література}

Кутзее, Дж.М. (2017). Безчестя: роман [пер. $з$ англ. С. Даскал]. Харків: Книжковий клуб «Клуб Сімейного Дозвілля».

Пшенична, М.С. (2017). Рецепція творчості Дж. М. Кутзее в сучасному літературознавстві. Вчені записки Таврійського національного університету імені В. І. Вернадського. Серія: Філологія. Соціальні комунікації, 28(67), 1, 27-32. http://nbuv.gov.ua/UJRN/UZTNU_filol_ 2017 28\%2867\%29_1_6 
118 Наукові записки ХНПУ ім. Г.С. Сковороди. Літературознавство, 2020, вип. 2(96)

Azoulay, A. (2002). An Alien Woman/A Permitted Woman: On J.M. Coetzee's Disgrace. Scrutiny, 27, 33-41.

Coetzee, J. M. (2000). Disgrase. London: Vintage Books.

Dekoven, M. (Winter, 2009). Going to the Dogs in «Disgrace». ELH, 76(4), 847875. URL: http://www.jstor.org/stable/27742965

Dimitriu, I.Ş. (2019). Utopia and dystopia: 'A brave new world' and the case of JM Coetzee. B.A.S. British and American Studies, 25, 133-142. Retrieved from https://www.ceeol.com/search/article-detail?id=803349

Giles, J. (2012). Of Gods and Dogs: The Post/Colonial Sublime in Coetzee's Disgrace, or, David Lurie's Aesthetic Education. Retrieved from https:// www.academia.edu/1788734/_Of_Gods_and_Dogs_The Post_Colonial Sublime_in_Coetzee_s_Disgrace_or_David_Lurie_s_Aesthetic_ Education

Griesse, Dörte. (2012). Dog-Man or God-Man? Animal Issues in J.M. Coetzee's «Disgrace». [Essay, Uni Bonn, Summer 2012]. Retrieved from https:// www.academia.edu/6680605/Dog_Man_or_God_Man_Animal_Issues_ in_J_M_Coetzees_Disgrace_Essay_Uni_Bonn_Summer_2012

Haraway, D. (2008) When Species Meet. Minneapolis; London: University of Minnesota Press.

Harrington, A. (2013). The Myth of the Criminal and Animal Subjecthood in J.M. Coetzee's Disgrace. Retrieved from https://fau.digital.flvc.org/ islandora/object/fau\%3A4095/datastream/OBJ/view/myth_of_the criminal_and_animal_subjecthood_in_J_M_Coetzee_s_Disgrace.pdf

Heerden, A. (2010). Disgrace, Desire, and the Dark Side of the New South Africa. In A. Leist \& P. Singer (Eds.), J.M. Coetzee and Ethics: Philosophical Perspectives on Literature (pp. 43-64). New York: Columbia University Press. doi:10.7312/leis14840.5

Herron, T. (Winter, 2005). The Dog Man: Becoming Animal in Coetzee's «Disgrace». Twenty Centure Literature, 51(4), 467-490. Retrieved from http://www.jstor.org/stable/20058782

J.M. Coetzee and the Ethics of Reading: Literature in the Event, University of Chicago Press, 2004.

Kossew, S. (2003). The Politics of Shame and Redemption in J.M. Coetzee's Disgrace. Research in African Literatures, 34 (2), 155-162.

Kucaia, B. (2014). The Rights and Wrongs of Desire: J.M. Coetzee's 'Disgrace' and Andrŭ Brink's 'The Rights of Desire'. Studia Litteraria Universitatis 
Iagellonicae Cracoviensis, 2, 141-150. Retrieved from https://www.ceeol. $\mathrm{com} / \mathrm{search} /$ article-detail?id=429137

Nyman, J. (2003). Postcolonial Animal Tale from Kipling to Coetzee. New Delhi: Atlantic.

Nyman, J. (2004). Introduction. Towards Animal Cultural Studies. In J. Nyman \& C Smith, (Eds.), Animal Magic. Essays on Animals in the American Imagination. (Vol. 11, Studies in Literature and Culture). Joensuu: Faculty of Humanities, University of Joensuu, 1-20.

Philippou, Eleni. (2016). Dogs, Horses, and Red Herrings: The Animal in J.M. Coetzee's The Childhood of Jesus. Retrieved from https://www. academia.edu/29189557/Dogs_Horses_and_Red_Herrings_The Animal_in_J_M_Coetzee_s_The_Childhood_of_Jesus

Pölling-Vocke, B. (2004, August). The stylistic purpose of animals and the disgrace of a nation in J.M.Coetzee's «Disgrace». Retrieved June 26, 2017, from http://www.hockeyarenas.com/disgrace.htm (Дата звернення: 16.11.2020).

Poyner, J. (2000). Truth and Reconciliation in J.M. Coetzee's Disgrace. Scrutiny: Issues in English Studies in South Africa, 5(2), 67-77.

Rosemary, J. (2006). Going to the dogs: humanity in J.M. Coetzee's Disgrace, The Lives of Animals and South Africa's Truth and Reconciliation Commission. Retrieved from https://books.google.com.ua/

Smit-Marais, S. (2006). Subverting the pastoral: the transcendence of space and place in J.M. Coetzee's «Disgrace». Literator, 27, 23-45.

Spencer, J., Ryan D. \& Edwards K.L. (Eds.). (2019). Reading Literary Animals: Medieval to Modern. New York, NY: Routledge.

Stolker, Marliene (2015). Coetzee's Traumatized Creatures: Toward a PostAnthropocentric and Posthumanist Understanding of Trauma. Retrieved from https://www.academia.edu/20402720/Coetzee_s_Traumatized Creatures_Toward_a_Post_Anthropocentric_and_Posthumanist_ Understanding_of_Trauma

Vallasek, J. (2011). A kegyetlenség hangjai, a gondoskodás csöndje Holmi, 10, 1285-1295. Retrieved from https://www.ceeol.com/search/ article-detail?id $=95018$

Wiegandt, K. (2013). J.M. Coetzee's “Dog-Man” and the Cynicism of Disgrace. Retrieved from https://www.researchgate.net/publication/287043621 
120 Наукові записки ХНПУ ім. Г.С. Сковороди. Літературознавство, 2020, вип. 2(96)

\section{References}

Coetzee, J. M. (2017). Disgrase: a novel [lane. from English. E. Daskal]. Kharkiv: Book Club «Family Leisure Club». (Coetzee J. M. Bezchestya: roman / Dzhon Maksvell Coetzee. Kharkiv: Knyzhkovyy klub «Klub Simeynoho Dozvillya»).

Pshenychna, M. S. (2017). Reception of JM Kutzee's work in modern literary criticism. Scientific notes of Tavriya National University named after VI Vernadsky. Series: Philology. Social Communications, 28(67), 1, 27-32. Retrieved from

http://nbuv.gov.ua/UJRN/UZTNU_filol_2017_28\%2867\%29_1_6.

Azoulay, A. (2002). An Alien Woman/A Permitted Woman: On J.M. Coetzee's Disgrace. Scrutiny, 27, 33-41.

Coetzee, J. M. (2000). Disgrase. London: Vintage Books.

Dekoven, M. (Winter, 2009). Going to the Dogs in «Disgrace». ELH, 76(4), 847875. URL: http://www.jstor.org/stable/27742965

Dimitriu, I.Ş. (2019). Utopia and dystopia: 'A brave new world' and the case of JM Coetzee. B.A.S. British and American Studies, 25, 133-142. Retrieved from https://www.ceeol.com/search/article-detail?id=803349

Giles, J. (2012). Of Gods and Dogs: The Post/Colonial Sublime in Coetzee's Disgrace, or, David Lurie's Aesthetic Education. Retrieved from https:// www.academia.edu/1788734/_Of_Gods_and_Dogs_The_Post_Colonial_ Sublime_in_Coetzee_s_Disgrace_or_David_Lurie_s_Aesthetic_Education

Griesse, Dörte. (2012). Dog-Man or God-Man? Animal Issues in J.M. Coetzee's «Disgrace». [Essay, Uni Bonn, Summer 2012]. Retrieved from https:// www.academia.edu/6680605/Dog_Man_or_God_Man_Animal_Issues_ in_J_M_Coetzees_Disgrace_Essay_Uni_Bonn_Summer_2012

Haraway, D. (2008). When Species Meet. Minneapolis; London: University of Minnesota Press.

Harrington, A. (2013). The Myth of the Criminal and Animal Subjecthood in J.M. Coetzee's Disgrace. Retrieved from https://fau.digital.flvc.org/ islandora/ object/fau\%3A4095/datastream/OBJ/view/myth_of_the criminal_and_animal_subjecthood_in_J_M_Coetzee_s_Disgrace.pdf Heerden, A. (2010). Disgrace, Desire, and the Dark Side of the New South Africa. In A. Leist \& P. Singer (Eds.), J.M. Coetzee and Ethics: Philosophical Perspectives on Literature (pp. 43-64). New York: Columbia University Press. doi:10.7312/leis14840.5 
Herron, T. (Winter, 2005). The Dog Man: Becoming Animal in Coetzee's «Disgrace». Twenty Centure Literature, 51(4), 467-490. Retrieved from http://www.jstor.org/stable/20058782

J.M. Coetzee and the Ethics of Reading: Literature in the Event. University of Chicago Press, 2004.

Kossew, S. (2003). The Politics of Shame and Redemption in J.M. Coetzee's Disgrace. Research in African Literatures, 34 (2), 155-162.

Kucaia, B. (2014). The Rights and Wrongs of Desire: J.M. Coetzee's 'Disgrace' and Andrŭ Brink's 'The Rights of Desire'. Studia Litteraria Universitatis Iagellonicae Cracoviensis, 2, 141-150. Retrieved from https://www. ceeol. $\mathrm{com} / \mathrm{search} /$ article-detail? $\mathrm{id}=429137$

Nyman, J. (2003). Postcolonial Animal Tale from Kipling to Coetzee. New Delhi: Atlantic.

Nyman, J. (2004). Introduction. Towards Animal Cultural Studies. In J. Nyman \& C Smith, (Eds.), Animal Magic. Essays on Animals in the American Imagination. (Vol. 11, Studies in Literature and Culture). Joensuu: Faculty of Humanities, University of Joensuu, 1-20.

Philippou, Eleni. (2016). Dogs, Horses, and Red Herrings: The Animal in J.M. Coetzee's The Childhood of Jesus. Retrieved from https://www. academia.edu/29189557/Dogs_Horses_and_Red_Herrings_The_ Animal_in_J_M_Coetzee_s_The_Childhood_of_Jesus

Pölling-Vocke, B. (2004, August). The stylistic purpose of animals and the disgrace of a nation in J.M.Coetzee's «Disgrace». Retrieved June 26, 2017, from http://www.hockeyarenas.com/disgrace.htm (Дата звернення: 16.11.2020).

Poyner, J. (2000). Truth and Reconciliation in J.M. Coetzee's Disgrace. Scrutiny: Issues in English Studies in South Africa, 5(2), 67-77.

Rosemary, J. (2006). Going to the dogs: humanity in J.M. Coetzee's Disgrace, The Lives of Animals and South Africa's Truth and Reconciliation Commission. Retrieved from https://books.google.com.ua/

Smit-Marais, S. (2006). Subverting the pastoral: the transcendence of space and place in J.M. Coetzee's «Disgrace». Literator, 27, 23-45.

Spencer, J., Ryan D. \& Edwards K.L. (Eds.). (2019). Reading Literary Animals: Medieval to Modern. New York, NY: Routledge.

Stolker, Marliene (2015). Coetzee's Traumatized Creatures: Toward a PostAnthropocentric and Posthumanist Understanding of Trauma. Retrieved from https://www.academia.edu/20402720/Coetzee_s_Traumatized_ 
Creatures_Toward_a_Post_Anthropocentric_and_Posthumanist_ Understanding_of_Trauma

Vallasek, J. (2011). A kegyetlenség hangjai, a gondoskodás csöndje. Holmi,

10, 1285-1295. Retrieved from https://www.ceeol.com/ search/ article-detail?id $=95018$

Wiegandt, K. (2013). J.M. Coetzee's “Dog-Man” and the Cynicism of Disgrace.

Retrieved from https://www.researchgate.net/publication/287043621

\section{Анотація \\ А.Я. Полторацька. Динаміка сприйняття тварин Девідом Лур'с у романі Джона Максвелла Кутзее «Безчестя»}

Мета статті - прослідкувати метаморфозу Девіда Лур'є та його ставлення до тварин у романі Джона Максвелла Кутзее «Безчестя».

Теоретичну базу дослідження становлять праці Дж. Агамбена, Ж. Симондона, Ж. Дерріди, Т. Інгольда, Л. Калоф, А. Ліппіт, Е. Фадж, Р. Брайдотті та ін. Вони забезпечили комплексний підхід до розуміння проблеми та системність дослідження.

Із огляду на мету й предмет дослідження в роботі використано: порівняльний аналіз критичних праць для окреслення основних тенденцій специфіки творчості Дж.М. Кутзее в українському та зарубіжному літературознавстві; герменевтичний аналіз художнього тексту, необхідний для виявлення специфіки ставлення Девіда Лур'є до тварин. Крім того, застосовано елементи описового й рецептивно-інтерпретаційного методів.

Традиційно людство трактувало тварину як істоту, яка підпорядковувалася людині і стояла на одному 3 нижніх щаблів ієрархічної драбини. Ч. Дарвін виступив проти цієї опозиції та змінив узвичаєне сприйняття людини. Його праці поставили під сумнів трактування тварини як «автомата» без мови, без почуттів та без розуму. Сучасні письменники прагнуть переосмислити протистояння людини й тварини. Джон Максвелл Кутзее в романі «Безчестя» теж не оминає цю проблему. Автор констатує кризу антропоцетричного світогляду. У романі «Безчестя» він прагне показати трансформацію світогляду головного персонажа під впливом життя на фермі. На початку твору Девід впевнений чоловік і не цікавиться тваринами; проте наприкінці твору він зовсім інший. Переворот у розумінні світу професора пов'язаний із кількома визначальними моментами його життя: завершенням відносин 
iз коханкою Серайєю, домаганнями до студентки, спілкуванням із Люсі, роботою в притулку та смертю собаки. Таким чином, взаємодія між головним персонажем та тваринами впливає на світосприйняття Девіда та розуміння ним світу природи, світу тварин та місце людини на Землі. Кутзее пропонує власну теорію про тварин, яка спонукає людство до переосмислення свого місця у світі.

Роман Кутзее відкриває новий етап осмислення взаємодії між людиною та твариною, що потребує детального вивчення та становить перспективу наших подальших досліджень.

Ключові слова: тварина, людина, безчестя, Кутзее.

\section{Аннотация \\ А.Я. Полторацкая. Динамика восприятия животных Девидом Лурье в романе Джона Максвелла Кутзее «Бесчестье»}

Цель статьи - проследить метаморфозу Дэвида Лурье и его отношение к животным в романе Джона Максвелла Кутзее «Бесчестье».

Теоретическую базу исследования составляют труды Дж. Агамбена, Ж. Симондона, Ж. Дерриды, Т. Інгольда, Л. Калоф, А. Липпит, Е. Фадж, Р. Брайдотти и других. Они способствовали комплексному подходу к пониманию проблемы и обеспечили системность исследования.

Учитывая цель и предмет исследования, в работе использованы: сравнительный анализ критических работ для определения основных тенденций специфики творчества Дж.М. Кутзее в украинском и зарубежном литературоведении; герменевтический анализ художественного текста, который необходим для выявления специфики отношения Дэвида Лурье к животным. Кроме того, применены элементы описательного, и рецептивноинтерпретационного методов.

Традиционно человечество воспринимало животное как существо, которое подчинялось человеку и располагалось ниже его на иерархической лестнице. Ч. Дарвин оспорил эту оппозицию и изменил общепринятое восприятие человека. Его труды поставили под сомнение трактовку животного как «автомата» без языка, без чувств и без ума. Современные писатели стремятся переосмыслить противостояние человека и животного. 
Джон Максвелл Кутзее в романе «Бесчестье» также обращается к этой проблеме. Он констатирует кризис антропоцентрического мировоззрения. В романе «Бесчестье» писатель стремится показать трансформацию мировоззрения главного персонажа под влиянием жизни на ферме. В начале произведения Дэвид - уверенный в себе мужчина, который не интересуется животными; однако в конце произведения он совсем другой. Переворот в понимании мира профессора связан с несколькими определяющими моментами его жизни: завершением отношений с любовницей Серайей, сексуальными домогательствами по отношению к студентке, общением с Люси, работой в приюте и смертью трехногого друга. Таким образом, взаимодействие между главным персонажем и животными влияет на мировосприятие Дэвида и понимание им мира природы и места человека на Земле. Кутзее предлагает собственную теорию о животных, побуждая читателя к переосмыслению своего места в мире.

Роман Кутзее открывает современный этап взаимодействия между человеком и животным, который требует подробного изучения, что составляет перспективу наших дальнейших исследований.

Ключевые слова: животное, человек, восприятие, бесчестье, Кутзее.

\section{Abstract \\ A.Ya. Poltoratska. The Dynamic of David Lurie's Perception of Animals in John Maxwell Coetzee's Novel «Disgrace»}

The aim of article is to trace the metamorphosis of David Lurie and his attitude to animals in the novel John Maxwell Coetzee «Disgrace».

The theoretical basis of the study is the works of G. Agamben, G. Simondon, J. Derrida, T. Ingold, L. Kaloff, A. Lippit, E. Fudge, R. Braidotti and others. Their works are contributed to a comprehensive approach to understanding the problem and provided systematic studies of Coetzee's novels.

Given the aim and subject of research in the work used: comparative analysis of critical works to outline the main trends in the specifics of the work of J.M. Coetzee in Ukrainian and foreign literary studies; hermeneutic analysis of the literary text, which is necessary to identify the specifics of David Lurie's attitude to animals. In addition, elements of descriptive, and receptiveinterpretive methods were used. 
Traditionally, mankind has treated an animal as a creature that was subordinate to man and was lower in the hierarchical gradation of the world. Charles Darwin challenged this opposition and changed the usual perception of man. His works called into question the interpretation of the animal as a «machine» without language, without feelings and mind. Modern writers seek to rethink the confrontation between man and animal. John Maxwell Coetzee in the novel «Disgrace» also does not ignore this problem. The author states the crisis of the anthropocentric worldview. In the novel «Disgrace» he seeks to show the transformation of the worldview of the main character under the influence of life on the farm. At the beginning of the work, David is a confident man and not interested in non-humans; however, at the end of the work he is completely different. The revolution in understanding of the professor's world is connected with several defining moments of his life: the end of his relationship with his lover Seraia, the harassment of a female-student, communication with Lucy, work in a shelter and the death of his three-legged friend. Thus, the interaction between the main character and the animals affects David's worldview and his understanding of the world of nature, the world of non-humans and the place of man on Earth. Coetzee offers his own theory of animals, which encourages a reader to rethink his place in the world.

Coetzee's novel opens the current stage of human-animal interaction, which requires detailed study, which is the perspective of our further research.

Keywords: animal, human, perception, disgrace, Coetzee.

Рукопис статті отримано 1 грудня 2020

Рукопис затверджено до публікаиії 14 грудня 2020

\section{Інформація про автора}

Полторацька Алла Яківна - вчитель зарубіжної літератури Українського колежу №272 м. Києва; вулиця Митрополита Андрія Шептицького, 5А, Київ, 02000, Україна; e-mail: apoltoratska@gmail.com; https://orcid.org/0000-0002-6941-6907 